\title{
Integrated Management of Soil Borne Diseases by Improving Soil Health with Physical and Chemical Treatments
}

\author{
Vikas Gupta ${ }^{1}$, V.K. Razdan ${ }^{2}$, Vishal Gupta ${ }^{2 *}$, Sachin Gupta ${ }^{2}$ and Upma Dutta ${ }^{3}$ \\ ${ }^{1}$ Krishi Vigyan Kendra-Leh, ${ }^{2}$ Division of Plant Pathology, ${ }^{3}$ Division of Micro Biology, Sher-e- \\ Kashmir University of Agricultural Sciences and Technology of Jammu, \\ Chatha, Jammu, India \\ *Corresponding author
}

A B S T R A C T

Keywords

Bio-agents, Compost, Soil moisture, Soil solarisation, Soil temperature

Article Info

Accepted: 16 March 2018 Available Online: 10 April 2018
Soil-borne diseases result from a reduction of biodiversity of soil organisms. Restoring beneficial organisms that attack, repel, or otherwise antagonize disease-causing pathogens render a soil disease-suppressive. Plants growing in such suppressive soil resist diseases much better than in soils low in biological diversity. Beneficial organisms increased to the soil environment through the use of compost and other organic amendments. Soil solarization significantly increased in soil temperature $\left(10-12^{\circ} \mathrm{C}\right)$ was observed as compared to non-solarized plots at 5,10 and $15 \mathrm{~cm}$ depths, however, maximum rise in temperature $\left(58^{\circ} \mathrm{C}\right.$ and $\left.56.1^{\circ} \mathrm{C}\right)$ was recorded at $5 \mathrm{~cm}$ depth during 2013 and 2014, respectively. Further soil solarisation was also found effective in reducing the pathogen population.

\section{Introduction}

Soil borne diseases are the major constraints in the successful cultivation of crop and a number of pathogens have been found to be associated with such diseases, of which Fusarium oxysporum, Rhizoctonia solani and Pythium aphanidermatum (fungi), Ralstonia solanacearum (bacterium) and Meloidogyne incognita (root knot nematode) are the most common (Doolittle, 1953; Das and
Chattopadhyay, 1955; Darekar and Mhase, 1988). Managing the soil borne diseases though quite difficult, however, various measures have been adopted to manage them with the aim to either eliminate or reduce the primary inoculum in soil in or on the seed or propagating material, besides making the hosts evade or defend the attack of the pathogens involved. Soil solarization is a simple nonchemical technique that captures radiant heat energy from the sun which leads to 
control or suppression of soil borne plant pathogens such as fungi, bacteria, nematodes, and pests along with weed seed and seedlings. Under suitable climatic conditions, solarization can control a wide spectrum of soil borne pests including fungi, bacteria, weeds and insects (Gamliel and Stapleton, 1993).

Soil solarization, a hydrothermal process, was studied for assessment of its effect on physical (temperature, $\mathrm{pH}$ and moisture) properties of soil. Several workers have reported increase in temperature and conservation of soil moisture while soil solarization due to the trapping of the solar energy by polyethylene sheets and preventing the heat loss caused by evaporation and convection, thus creating a greenhouse effect (Elad et al., 1980; Katan, 1981). Soil solarization integrated with different amendments and bioagents increases the efficacy of soil solarization and prolonged effectiveness of soil solarization.

\section{Materials and Methods}

\section{Soil solarization}

The nursery beds were irrigated to the level of field capacity to ensure the presence of adequate moisture during the period of solarization. These beds were covered with low density transparent polyethylene sheets of $25 \mu \mathrm{m}$ thickness, placing the ends of the sheets in furrows and buried with compact soil to ensure that all the edges were thoroughly sealed.

In order to record the soil temperature, soil thermometers were placed at 5, 10 and $15 \mathrm{~cm}$ soil depths, beneath the polyethylene sheets, during the entire period of solarization. Temperature of the uncovered (non-solarized) plots was also recorded. Soil temperatures were recorded daily at 06.00 and 14.00 hours and interpreted in results on weekly basis.

\section{Soil amendments}

Decomposed Farm Yard Manure (FYM) was inoculated with most effective fungal and bacterial biocontrol agents viz., Trichoderma viride isolate $\mathrm{Tv}_{4}\left(1 \mathrm{x} \quad 10^{7} \mathrm{cfu} / \mathrm{ml}\right)$ and Pseudomonas fluorescens isolate $\mathrm{Pf}_{2}\left(1 \times 10^{8}\right.$ $\mathrm{cfu} / \mathrm{ml}$ ) and then applied to the nursery fields @ $2000 \mathrm{~g} / \mathrm{m}^{2}$. Spent compost of button mushroom i.e., compost left after harvesting of mushroom was added to the nursery beds (a $2000 \mathrm{~g} / \mathrm{m}^{2}$. The details of the treatments are as: $\mathrm{T}_{1}=$ Soil solarisation, $\mathrm{T}_{2}=$ Soil fumigation, $\mathrm{T}_{3=}$ Non-solarized soil + Trichoderma viride + FYM@ 1000 g/m², T4= Non-solarized soil + Pseudomonas fluorescens + FYM @ 1000 $\mathrm{g} / \mathrm{m}^{2}, \mathrm{~T}_{5}=$ Spent compost of button mushroom @ $1000 \mathrm{~g} / \mathrm{m}^{2}$ and $\mathrm{T}_{6}=$ Control (untreated plots). All the experiments were conducted in Randomized Block Design with three replications at Research Farm at Sher-eKashmir University of Agricultural Sciences and Technology of Jammu.

\section{Observations regarding microbial population}

Microbial population in different treatments were recorded by analyzing soil samples using soil dilution plate method (Dhingra and Sinclair, 1995). Fungal population was recorded by counting the number of colonies developed on PDA after plating $1 \mathrm{ml}$ of $10^{-4}$ dilution in a petriplate. For evaluating bacterial load $1 \mathrm{ml}$ of $10^{-6}$ dilution was used for plating on Nutrient Agar (Allen, 1957). Actinomycete population was counted on Actinomycetes Specific Medium (ASM) by plating $1 \mathrm{ml}$ of $10^{-7}$ dilution (Kuznetsov and Rao, 1972).

Population of nematodes was recorded from different treatments. To isolate nematode the soil samples from different locations were processed by sieving and decanting method (Cobb, 1918). 


\section{Results and Discussion}

\section{Soil temperature}

The average soil temperature profiles recorded at 5,10 and $15 \mathrm{~cm}$ depths in both solarized and non-solarized plots are presented in Table 1. In the year 2013, maximum soil temperature in the non-solarized plots at $5 \mathrm{~cm}$ depth ranged from 37 to $47^{\circ} \mathrm{C}$ and in solarized plots from 47.8 to $58.8^{0} \mathrm{C}$, whereas, the minimum soil temperature in non-solarized plots ranged from 14.1 to $25^{\circ} \mathrm{C}$, and in solarized plots from 23.9 to $34.3^{0} \mathrm{C}$.

At $10 \mathrm{~cm}$ depth the maximum soil temperature in non-solarized plots was 32.7 to $43.5^{\circ} \mathrm{C}$ and in solarized plots 40.6 to $51.5^{\circ} \mathrm{C}$, whereas, minimum temperature in non-solarized plots ranged from 17.6 to $25.6^{\circ} \mathrm{C}$ and in solarized plots 23.6 to $30.4^{0} \mathrm{C}$. Similarly, at $15 \mathrm{~cm}$ depth, the average maximum soil temperature in non-solarized plots ranged from 28 to $38.9^{\circ} \mathrm{C}$, and in solarized plots from 34.2 to $46.1^{\circ} \mathrm{C}$, whereas, the minimum temperature in non-solarized plots varied from 19.3 to $28.5^{\circ} \mathrm{C}$ and in solarized plots from 27.4 to $35^{\circ} \mathrm{C}$.

In the year 2014, maximum soil temperature in the non-solarized and solarized plots at $5 \mathrm{~cm}$ depth ranged from 32.6 to $44.6^{\circ} \mathrm{C}$ and 44.2 to $56.1^{\circ} \mathrm{C}$, whereas, the minimum soil temperature ranged from 17.4 to $24.2^{\circ} \mathrm{C}$ and 26.8 to $34.6^{0} \mathrm{C}$, respectively.

At $10 \mathrm{~cm}$ depth the maximum soil temperature recorded in the non-solarized and solarized plots ranged from 32.5 to $38.3^{\circ} \mathrm{C}$ and 41 to $50^{\circ} \mathrm{C}$, whereas, the minimum soil temperature from 20.6 to $28.2^{0} \mathrm{C}$ and 26.5 to $35.2^{\circ} \mathrm{C}$, respectively. Similarly, at $15 \mathrm{~cm}$ depth maximum temperature in the non-solarized and solarized plots ranged from 27.6 to $38.8^{\circ} \mathrm{C}$ and 35.9 to $43.1^{\circ} \mathrm{C}$, whereas, the minimum temperature ranged from 22 to $29.9^{\circ} \mathrm{C}$ and $30.2^{0} \mathrm{C}$ to $37.1^{0} \mathrm{C}$, respectively.

\section{Microbial population}

Soil samples collected from nursery plots, given different treatments, were examined for the presence of microbial population.

\section{Fungal population}

A perusal of data presented in the Table 2 reveal that in the year 2013, fungal population in the solarized nursery plots was minimum $\left(13.67 \times 10^{4}\right)$, it was followed by fumigated nursery plots $\left(15.33 \times 10^{4}\right)$. Fungal population was maximum in spent compost treated plots $\left(47.67 \times 10^{4}\right)$, followed by plots amended with FYM + Tv $_{4}\left(33.67 \times 10^{4}\right)$ and plots with FYM treated with $\mathrm{Pf}_{2}\left(29.67 \times 10^{4}\right)$. In non-solarized control plots the fungal population recorded was $26.33 \times 10^{4}$. Similar trend was observed in the year 2014 .

\section{Bacterial population}

In the year 2013, bacterial count recorded (Table 2) from solarized nursery plots and fumigated nursery plots was minimum $\left(40.33 \times 10^{6}\right.$, in each), which was followed by fumigated nursery plots $\left(43.33 \times 10^{6}\right)$. Bacterial population was maximum in plots amended with spent compost $\left(86.33 \times 10^{6}\right)$, followed by plots having FYM treated $\mathrm{Tv}_{4}\left(81.67 \times 10^{6}\right)$ and FYM treated with $\mathrm{Pf}_{2}\left(78.33 \times 10^{6}\right)$. In the nonsolarized plots the bacterial count was $75.33 \times 10^{6}$. Similar trend was observed in the year 2014.

\section{Actinomycetes population}

The data presented in Table 2 further revealed that in the year 2013, the actinomycetes count recorded from fumigated nursery plots was minimum $\left(11.33 \times 10^{5}\right)$, followed by plots amended with spent compost $\left(11.67 \times 10^{5}\right)$. Actinomycetes population was maximum $\left(22.67 \times 10^{5}\right)$ in solarized nursery plot. In the control plots the population was $15.33 \times 10^{5}$. 
Table.1 Soil temperature recorded at different depths from solarized and non-solarized plots during 2013 and 2014

\begin{tabular}{|c|c|c|c|c|c|c|c|c|c|c|c|c|}
\hline \multirow{4}{*}{$\begin{array}{l}\text { Meteorological } \\
\text { Standard Week }\end{array}$} & \multicolumn{12}{|c|}{ Soil temperature $\left({ }^{0} \mathrm{C}\right)$ at different depths } \\
\hline & \multicolumn{6}{|c|}{ Non-solarized plots } & \multicolumn{6}{|c|}{ Solarized plots } \\
\hline & \multicolumn{2}{|c|}{$5 \mathrm{~cm}$} & \multicolumn{2}{|c|}{$10 \mathrm{~cm}$} & \multicolumn{2}{|c|}{$15 \mathrm{~cm}$} & \multicolumn{2}{|c|}{$5 \mathrm{~cm}$} & \multicolumn{2}{|c|}{$10 \mathrm{~cm}$} & \multicolumn{2}{|c|}{$15 \mathrm{~cm}$} \\
\hline & Max & Min & Max & Min & Max & Min & Max & Min & Max & Min & Max & Min \\
\hline \multicolumn{13}{|l|}{ Year 2013} \\
\hline 16 & 37.0 & 14.1 & 32.7 & 17.6 & 28.0 & 19.3 & 47.8 & 23.9 & 40.6 & 23.6 & 34.2 & 27.4 \\
\hline 17 & 38.5 & 16.5 & 34.1 & 21.2 & 28.4 & 22.8 & 49.7 & 26.5 & 43.4 & 28.0 & 37.8 & 30.9 \\
\hline 18 & 43.1 & 19.0 & 36.6 & 23.3 & 32.1 & 25.7 & 55.0 & 29.0 & 45.7 & 28.2 & 40.6 & 33.6 \\
\hline 19 & 44.7 & 17.1 & 39.7 & 22.0 & 34.8 & 24.4 & 56.9 & 26.8 & 48.0 & 26.3 & 42.5 & 30.7 \\
\hline 20 & 47.0 & 19.5 & 43.5 & 24.0 & 38.9 & 26.9 & 58.8 & 29.2 & 51.5 & 29.0 & 46.1 & 33.8 \\
\hline 21 & 44.5 & 25.0 & 39.6 & 25.6 & 34.0 & 28.5 & 56.6 & 34.3 & 48.1 & 30.4 & 42.6 & 35.0 \\
\hline 22 & 46.8 & 18.8 & 41.8 & 24.7 & 37.7 & 27.0 & 57.0 & 28.4 & 50.9 & 30.0 & 44.3 & 34.0 \\
\hline \multicolumn{13}{|l|}{ Year 2014} \\
\hline 16 & 34.9 & 17.4 & 32.5 & 20.6 & 27.6 & 22.0 & 46.2 & 26.8 & 41.0 & 26.5 & 35.9 & 30.2 \\
\hline 17 & 32.6 & 19.0 & 34.9 & 23.2 & 28.1 & 23.5 & 44.2 & 29.0 & 43.7 & 29.0 & 37.4 & 32.0 \\
\hline 18 & 37.7 & 19.9 & 34.4 & 23.4 & 31.2 & 25.5 & 50.0 & 29.9 & 43.4 & 29.8 & 40.0 & 33.5 \\
\hline 19 & 38.8 & 19.4 & 35.3 & 22.2 & 32.0 & 25.0 & 51.3 & 28.1 & 46.2 & 28.2 & 40.5 & 31.0 \\
\hline 20 & 42.0 & 21.7 & 37.2 & 24.8 & 32.3 & 26.1 & 54.4 & 31.3 & 46.9 & 31.7 & 41.1 & 34.9 \\
\hline 21 & 42.4 & 22.9 & 36.7 & 26.9 & 33.1 & 28.3 & 55.2 & 31.2 & 47.3 & 33.5 & 42.0 & 36.2 \\
\hline 22 & 44.6 & 24.2 & 38.3 & 28.2 & 33.8 & 29.9 & 56.1 & 34.6 & 50.0 & 35.2 & 43.1 & 37.1 \\
\hline
\end{tabular}

\section{Table.2 Effect of soil solarization and addition of soil amendments on the soil microbial population}

\begin{tabular}{|c|c|c|c|c|}
\hline \multirow[t]{2}{*}{ Treatment } & \multicolumn{3}{|c|}{ Average number of colonies (cfu/g of soil) } & \multirow{2}{*}{$\begin{array}{l}\text { Nematode } \\
\text { population per } \\
250 \mathrm{~g} \text { soil }\end{array}$} \\
\hline & $\begin{array}{l}\text { Fungi } \\
\left(1 \times 10^{4}\right)\end{array}$ & $\begin{array}{c}\text { Bacteria } \\
\left(1 \times 10^{6}\right)\end{array}$ & $\begin{array}{l}\text { Actinomycetes } \\
\left(1 \times 10^{5}\right)\end{array}$ & \\
\hline \multicolumn{5}{|l|}{ Year 2013} \\
\hline Soil solarization & $13.67 *(3.83)$ & $40.33(6.43)$ & $22.67(4.86)$ & $137.67(11.78)$ \\
\hline Soil fumigation & $15.33(4.04)$ & $43.33(6.66)$ & $11.33(3.51)$ & $148.67(12.22)$ \\
\hline Non-solarized soil + FYM + T. viride $\left(\mathrm{Tv}_{4}\right)$ & $33.67(5.89)$ & $81.67(9.09)$ & $12.33(3.65)$ & $155.33(12.50)$ \\
\hline Non-solarized soil + FYM + P. fluorescens $\left(\mathrm{Pf}_{2}\right)$ & $29.67(5.54)$ & $78.33(8.90)$ & $12.67(3.69)$ & $166.67(12.95)$ \\
\hline Non-solarized soil + SCM & $47.67(6.98)$ & $86.33(9.35)$ & $11.67(3.56)$ & $158.67(12.62)$ \\
\hline Non-solarized soil (check) & $26.33(5.23)$ & $75.33(8.74)$ & $15.33(4.04)$ & $437.00(20.93)$ \\
\hline${\mathrm{S} . \mathrm{E}_{\mathrm{m}}}( \pm)$ & 0.03 & 0.02 & 0.04 & 0.10 \\
\hline $\mathrm{CD}(\mathrm{P}=0.05)$ & 0.094 & 0.074 & 0.130 & 0.303 \\
\hline \multicolumn{5}{|l|}{ Year 2014} \\
\hline Soil solarization & $13.00(3.74)$ & $39.33(6.35)$ & $21.33(4.73)$ & $136.67(11.73)$ \\
\hline Soil fumigation & $16.67(4.20)$ & $44.67(6.76)$ & $12.67(3.69)$ & $150.67(12.31)$ \\
\hline Non-solarized soil $+\mathrm{FYM}+T$. viride $\left(\mathrm{Tv}_{4}\right)$ & $33.00(5.83)$ & $82.33(9.13)$ & $13.67(3.88)$ & $156.67(12.54)$ \\
\hline Non-solarized soil + FYM + P. fluorescens $\left(\mathbf{P f}_{2}\right)$ & $29.00(5.48)$ & $78.67(8.93)$ & $13.33(3.79)$ & $169.00(13.03)$ \\
\hline Non-solarized soil + SCM & $48.33(7.02)$ & $85.00(9.27)$ & $11.00(3.45)$ & $160.00(12.69)$ \\
\hline Non-solarized soil (check) & $25.67(5.16)$ & $74.00(8.66)$ & $14.67(3.96)$ & $441.33(21.02)$ \\
\hline S.E $E_{m}( \pm)$ & 0.04 & 0.02 & 0.05 & 0.10 \\
\hline $\mathrm{CD}(\mathrm{P}=0.05)$ & 0.131 & 0.063 & 0.163 & 0.326 \\
\hline
\end{tabular}

*Figures given in parenthesis are transformed (arc sin) values; Soil fumigation [5 L formalin solution per bed (1 $\left.\mathrm{m}^{2}\right)$ ]; FYM=Farm yard manure [2kg per bed $\left.\left(1 \mathrm{~m}^{2}\right)\right]$; SCM=Spent compost of mushroom [2kg per bed $\left.\left(1 \mathrm{~m}^{2}\right)\right]$

T. viride@10 $10^{7}$ spores per ml; P. fluorescens @ 10 $0^{8}$ colony forming units (cfu) per ml. 
In the year 2014 actinomycetes colonies recorded from plots amended with spent compost were minimum $\left(11 \times 10^{5}\right)$, followed by fumigated nursery plots $\left(12.67 \times 10^{5}\right)$.

Maximum actinomycetes colonies were recorded from solarized nursery plots $\left(21.33 \times 10^{5}\right)$. In the control plots (nonsolarized plots) the population recorded was $14.67 \times 10^{5}$.

Nematode Population: In the year 2013, minimum nematode population was recorded from solarized plots (137.67), which was followed by fumigated nursery plots (148.67), and plots amended with FYM treated with $\mathrm{Tv}_{4}$ (155.33). Maximum nematode population per $250 \mathrm{~g}$ soil was recorded from the nursery plots amended with FYM treated with $\mathrm{Pf}_{2}$ (166.67), followed by plots amended with spent compost (158.67). In non-solarized plots the population recorded was 437. Similar trend was observed in the year 2014.

Soil solarization, a hydrothermal process, was studied for assessment of its effect on physical (temperature, $\mathrm{pH}$ and moisture) properties of soil. Soil solarization significantly increased in soil temperature $\left(10-12^{\circ} \mathrm{C}\right)$ was observed as compared to nonsolarized plots at 5,10 and $15 \mathrm{~cm}$ depths, however, maximum rise in temperature (58 and $56.1^{\circ} \mathrm{C}$ ) was recorded at $5 \mathrm{~cm}$ depth during 2013 and 2014, respectively. Several workers have reported increase in temperature while soil solarization due to the trapping of the solar energy by polyethylene sheets and preventing the heat loss caused by evaporation and convection, thus creating a greenhouse effect (Elad et al., 1980; Katan, 1981). Chellemi et al., (1994) recorded the temperature profiles at different depths and found maximum increase of temperature at 5 $\mathrm{cm}$ depth. Khulbe and Chaube (2000) reported that mulching of pre-irrigated plots with polythene sheetings increased daily average temperature by $12-15^{\circ} \mathrm{C}$. In the solarized plots the $\mathrm{pH}$ recorded was significantly higher than other treatments which included soil fumigation, non-solarized soil + FYM + T. viride (isolate $\mathrm{Tv}_{4}$ ), nonsolarized soil $+\mathrm{FYM}+$ Pseudomonas fluorescens $\left(\mathrm{Pf}_{2}\right)$, non-solarized soil + spent compost and non-solarized soil (check). Sharma and Sharma (2004) also reported that $\mathrm{pH}$ was higher in the solarized plots as compared to non-solarized plots at 10 and 30 $\mathrm{cm}$ soil depths. The studies also revealed that at the end of solarization period the moisture conserved was significantly higher in solarized plots as compared to soil fumigation and non-solarized plots. In non-solarized plots, solar radiations falling on earth cause loss of moisture through evapotranspiration since white thin transparent polyethylene sheets provide insulation against escape of heat and moisture from soil (Chen and Katan, 1980; Katan, 1987; Ahmad et al., 1996). The rise in soil temperature resulted in decrease of fungal, bacterial and nematode population, whereas, there was increase in the actinomycetes population due to their thermophillic nature. Our findings are in conformity with different workers (Stapleton and De-Vay, 1982; Sharma et al., 2000; Sharma and Sharma, 2004; Verma and Sharma, 2005).

\section{References}

Ahmad, Y., Hameed, A. and Aslam, M. 1996. Effect of soil solarization on corn stalk rot. Plant Soil. 179: 17-24.

Allen, O.N. (ed.) 1957. Experiments in Soil Bacteriology, pp 117. Burgees Publishing Co. Minneapolis.

Chellemi, D.O., Olson, S.M. and Mitchell, D.J. 1994. Effect of soil solarization and fumigation on survival of soil borne pathogens of tomato in north Florida. Plant Disease. 78: 1167. 
Chen, Y. and Katan, J. 1980. Effect of solar heating of soils by transparent polyethylene mulching on their chemical properties. Soil Science. 130: 271-277.

Cobb, N.A. 1918. Estimating the nematode population of the soil. $\mathrm{p}$ 48. Agricultural circular No.1, United State Department of Agriculture.

Darekar, K.S. and Mhase, M.L. 1988. Assessment of yield losses due to root knot nematodes - Meloidogyne incognita Race 2 in tomato, brinjal and bitter gourd. International Nematology Network Newsletter, 5: 7-9.

Das, C.R. and Chattopadhyay, S.B. 1955. Bacterial wilt of eggplants. Indian Phytopathology. 8: 130-135.

Dhingra, O.D. and Sinclair, J.B.1995. Basic Plant Pathology Methods. $2^{\text {nd }}$ Edition Lewis Publishers, USA. 434p.

Doolittle, S.P. 1953. Diseases of pepper. In: Year Book of Agriculture pp. 465-469. Oxford and IBH Publishing Company, New Delhi.

Elad, Y., Chet, I. and Katan, J. 1980. Trichoderma harzianum: A biocontrol agent effective against Sclerotium rolfsii and Rhizoctonia solani. Disease Control and Pest Management 70: 119-121.

Gamliel, A. and Stapleton, J.J. 1997. Improvement of soil solarization with volatile compounds generated from organic amendments. Phytoparasitica. 25: 315-385

Katan, J. 1987. Solar Solarization: innovative approaches to Plant Disease Control. Chet, I. (ed). John Wiley and Sons, New York.
Katan, J.1981. Solar heating (Solarization) of soil for control of soil borne pests. Annual Review of Phytopathology. 19: 211-236.

Khulbe, D. and Chaube, H.S. (2000). Integration of soil solarization and organic amendments and its effect on soil properties and plant growth. Journal of Mycology \&.Plant Pathology.30: 269.

Kuznetsov, V.D. and Arjuna, R.V.1972. Actinomycetes antagonistic to phytopathogenic fungi from some South Indian soils. Indian Phytopathology. 25: 307-309.

Sharma, A. and Sharma, S.K. 2004. Effect of soil solarization on soilborne pathogens and soil microbial population in apple nurseries. Pant Disease Research. 20: $138-142$.

Sharma, S.K., Verma, V.S. and Sharma, M.2000. Effect of soil solarization on soil microflora with special reference to Fusarium solani in mango nursery. Journal of Mycology \&.Plant Pathology 30: 273.

Stapleton, J.J. and Devay, J.E. 1982. Effect of soil solarization on populations of selected soil borne organisms and growth of deciduous fruit tree seedlings. Phytopathology. 72: 323-326.

Verma, V.S. and Sharma, S.K. 2005. Effect of soil pasteurization with transparent polythene tarps on microbial population including mango with pathogen, Fusarium solani. Indian Phytopathology. 58: 375.

\section{How to cite this article:}

Vikas Gupta, V.K. Razdan, Vishal Gupta, Sachin Gupta and Upma Dutta. 2018. Integrated Management of Soil Borne Diseases by Improving Soil Health with Physical and Chemical Treatments. Int.J.Curr.Microbiol.App.Sci. 7(04): 1990-1995. doi: https://doi.org/10.20546/ijcmas.2018.704.229 